ISSN 1392-3196 / e-ISSN 2335-8947

Zemdirbyste-Agriculture, vol. 106, No. 4 (2019), p. 291-296

DOI 10.13080/z-a.2019.106.037

\title{
The effect of farming system and management practices on surface-dwelling soil macrofauna
}

\author{
Vojtěch CHMELÍK, Bořivoj ŠARAPATKA, Ondřej MACHAČ, Jan MIKULA, \\ Vratislav LAŠKA, Ivan H. TUF \\ Palacký University, Faculty of Science \\ Šlechtitelů 12, 77146 Olomouc, Czech Republic \\ E-mail: borivoj.sarapatka@upol.cz
}

\begin{abstract}
Whereas contemporary agriculture reduces invertebrate diversity, organic farming is expected to minimize this negative influence. In this study, we compared communities of surface-dwelling soil macrofauna from the fields farmed conventionally and organically over the last 15 years in the crop rotation with winter oilseed rape and winter wheat. A statistically higher number of specimens were caught in the conventional treatment of both crops. Ground beetles (i.e. beetles of the family Carabidae) and spiders were the most abundant groups. While spiders preferred organically managed fields, carabids tended to prefer the conventional system, as carabid communities were affected by springtime mechanical soil interventions (harrowing and hoeing). These interventions were insignificant to spiders as they over-winter in field margins, spread very well by air and are able to re-colonize agroecosystems quickly. This reveals that organic farming does not necessarily support the development of populations and communities of soil fauna.
\end{abstract}

Key words: Araneae, Carabidae, conventional farming, farming management, organic farming, soil fauna.

\section{Introduction}

With its influence on the environment, intensive agriculture is considered to be one of the main drivers in the decline in invertebrate species richness and community composition (Tscharntke et al., 2012). Organic agriculture is a farming and food production system, which combines best environmental practices, a high level of biodiversity, the preservation of natural resources, the application of high animal welfare standards and a production method in line with the preference of certain consumers for products produced using natural substances and processes (EC, 2007; Stockdale, Watson, 2009). This diversified farming system can also promote biocontrol services, e.g., by polyphagous predators such as Carabidae (Arus et al., 2012). Biodiversity and biocontrol services are affected also by landscape composition. The direct relationship between organic farming and landscape composition, especially the development of landscape elements, has not been proven unambiguously and organic farm cultural landscapes do not appear automatically as a by-product of the organic farming method (Levin, 2007). The results in Czech conditions, published by Dytrtová et al. (2016), showed differing trends in the studied locations, which do not depend on farm management alone but also on other factors, especially natural conditions in agricultural landscape.

Organic farming may offer benefits for a wide spectrum of taxa, but what influences these benefits is not well understood (Feber et al., 2015; Soderman et al., 2016).
A simple comparison between organic and conventional farming does not reflect the diversity of practices that may exist within each farming system (Vasseur et al., 2013). Some conventional farmers may use techniques similar to organic farming even if they are not certified, whereas some organic farmers may use organic inputs and frequent, deep tillage, which are allowed by the specifications but are potentially lethal to arthropods (Thorbek, Bilde, 2004). The effect of agricultural practices can differ according to the model group of affected organism. While the greatest effect of agricultural system is on plants, a less consistent impact was noted on carabid beetles (Fuller et al., 2005) or spiders (Schneider et al., 2014). Other factors, e.g., less heterogeneous landscape, can suppress the effect of agricultural system (Roschewitz et al., 2005; Schneider et al., 2014).

Ground beetles and spiders could be good bioindicators of the condition of fields (Cardoso et al., 2013) as they play an important role in agroecosystems (Bruno, Cardinale, 2008). Most species are predators (Kromp, 1999; Holland et al., 2005), whereas some carabids are important seed predators and can effectively reduce weed density in fields. For example, ground beetles are usually more diverse and abundant within organically farmed areas (Bengtsson et al., 2005). Spider abundance generally increases with increasing habitat diversification within and around farm crops (Sunderland, Samu, 2000); other comparisons find little or no difference in ground

Please use the following format when citing the article:

Chmelík V., Šarapatka B., Machač O., Mikula J., Laška V., Tuf I. H. 2019. The effect of farming system and management practices on surface-dwelling soil macrofauna. Zemdirbyste-Agriculture, 106 (4): 291-296. DOI 10.13080/z-a.2019.106.037 
beetle or spider species richness between organic and conventional fields (Fuller et al., 2005; Ekroos et al., 2010; Rahmann, 2011; Birkhofer et al., 2014). Both groups seem to be negatively affected not only by pesticide use (Riechert, 1998) but also by deep ploughing; on the other hand, reduced tillage systems (Kromp, 1999) as well as lower tillage frequency (Puech et al., 2014) can support their populations.

The current study looks at long-term operation of the organic farming system and compares this with practice and diversity in conventional farming. Using the example of soil invertebrates, with emphasis on carabids and spiders, the study focuses on identifying problematic management interventions, which influence their diversity.

\section{Materials and methods}

Study site. The research was carried out on experimental plots in Uhř́něves $\left(50^{\circ} 2^{\prime} 13.002^{\prime \prime} \mathrm{N}\right.$, $\left.14^{\circ} 37^{\prime} 1.956^{\prime \prime} \mathrm{E}\right)$ at the Czech University of Life Sciences in Prague, Czech Republic. According to figures at the Czech Hydrometeorological Institute, the climate of the territory is moderately continental with an average temperature of $9.2^{\circ} \mathrm{C}$ and precipitation of $515 \mathrm{~mm}$ with a maximum between late spring and summer, and a minimum in winter. The soil type at the locality is Haplic
Luvisol (WRB, 2014). Monitoring of agroecosystems in wheat was carried out over four years (2010-2014) and in oilseed rape over three years (2010-2013). These plots underwent a long-term comparative trial of organic and conventional farming, which began 15 years prior to the start of our monitoring. This means that, after such a long period, differences between the two agricultural approaches may be evident.

Experimental design. Within the crop rotation system on a 2-hectare experimental plots, we focused on the growth of winter rape (Brassica napus L.) and winter wheat (Triticum aestivum L.). In the conventional farming system both these crops were grown after a grainlegume mixture, while in the organic farming system the preceding crop was alfalfa. In individual years pitfall traps were set in each treatment within the experimental plot for late spring and summer. Soil samples were taken from each treatment twice a year. Both traps and soil samples were situated in the inner parts of experimental plots to avoid edge effect. The basic agro-technical methods in both crops were identical - a ploughing was used. The conventional treatment involved chemical input: in both crops readily soluble nitrogen in mineral fertilizer was applied in 2-3 applications amounting to $120-160 \mathrm{~kg} \mathrm{ha}^{-1} \mathrm{~N}$. A summary of interventions in both crops is shown in Table.

Table. Mechanical and agro-chemical interventions and their frequency in individual years in organically and conventionally cultivated crops

\begin{tabular}{|c|c|c|c|c|c|c|c|c|}
\hline \multirow{2}{*}{ Study year } & \multicolumn{4}{|c|}{ Organic treatment } & \multicolumn{4}{|c|}{ Conventional treatment } \\
\hline & $1^{\text {st }}$ & $2^{\text {nd }}$ & $3^{\text {rd }}$ & $4^{\text {th }}$ & $1^{\text {st }}$ & $2^{\text {nd }}$ & $3^{\text {rd }}$ & $4^{\text {th }}$ \\
\hline \multicolumn{9}{|c|}{ Winter oilseed rape } \\
\hline Hoeing & $2 \times$ & $2 \times$ & $2 \times$ & - & - & - & - & - \\
\hline Herbicides & - & - & - & - & $2 \times$ & $3 \times$ & $2 \times$ & - \\
\hline Insecticides & - & - & - & - & $2 \times$ & $1 \times$ & $1 \times$ & \\
\hline Yield t ha- ${ }^{-1}$ & 2.83 & 3.39 & 3.01 & - & 5.49 & 5.03 & 5.54 & - \\
\hline \multicolumn{9}{|c|}{ Winter wheat } \\
\hline Harrowing & $3 \times$ & $3 \times$ & $3 \times$ & $4 \times$ & - & - & - & - \\
\hline Herbicides & - & - & - & - & $2 \times$ & $1 \times$ & $1 \times$ & $2 \times$ \\
\hline Insecticides & - & - & - & - & $2 \times$ & $2 \times$ & $2 \times$ & $2 \times$ \\
\hline Fungicides & - & - & - & - & $2 \times$ & $2 \times$ & $2 \times$ & $2 \times$ \\
\hline Yield t ha ${ }^{-1}$ & 5.46 & 7.40 & 6.70 & 6.20 & 7.30 & 8.26 & 8.23 & 6.96 \\
\hline
\end{tabular}

Winter oilseed rape: herbicides $\left(\mathrm{g} \mathrm{L}^{-1}\right)$ metazachlor 400, clopyralid 267 and picloram 67; insecticides $\left(\mathrm{g} \mathrm{L}^{-1}\right)$ chlorpyrifos 500 and cypermethrin 50; winter wheat: herbicides $\left(\mathrm{g} \mathrm{L}^{-1}\right)$ fluroxypyr 333 and clopyralid 300 ; insecticides $\left(\mathrm{g} \mathrm{L}^{-1}\right)$ chlorpyrifos 500 , cypermethrin 50, thiacloprid 100 and deltamethrin 10; fungicides $\left(\mathrm{g} \mathrm{L}^{-1}\right)$ tebuconazole 250 and metconazole 60

Fauna sampling and processing. Soil invertebrates were sampled each year in spring-summer by two methods: pitfall trapping of ground-dwelling invertebrates and heat-extraction of soil-dwelling invertebrates from soil samples. (1) Five pitfall traps (plastic cups $7 \mathrm{~cm}$ in diameter with metal covers, filled with a $4 \%$ water formaldehyde solution) were set up in each field from April-May of each year and were emptied twice a month until July. The catches for each year in each of the fields were analysed. Such data is known as activity-density, as the number of animals entering traps is dependent on both activity and density. (2) Five soil samples (area of each 1/30 $\mathrm{m}^{2}, 15 \mathrm{~cm}$ depth) were taken twice a year (May and July) in each treatment of field and crop using a metal soil sampler. Soil invertebrates were heat-extracted from samples in simple thermoextractors during the subsequent 14 days and abundance of soil dwelling animals of individual groups was calculated (Tuf, Tvardík, 2005).

Statistical analysis. The abundance and activitydensity of soil invertebrates from plots of the same crop, but differing in management, were compared using the $\chi^{2}$ test comparing the difference between the two ratios. Quantitative data of activity-density patterns of individual species from pitfall traps was evaluated by the programme Canoco for Windows, version 4.5 (ter Braak, Smilauer, 1998). The effect of different forms of management on the distribution of ground beetles and spiders was evaluated by unimodal principal component analysis (PCA), and the best model was selected using Monte-Carlo permutation tests. The form of management (organic $v s$ conventional) and crop (wheat $v s$ oilseed rape) were used as environmental variables, whereas the year of sampling was used as a co-variable. Species of ground beetles and spiders of which overall catch exceeded 10 individuals were used as species variables.

\section{Results}

When evaluating the results obtained, we focused on the selected groups of soil fauna in conventional and organic farming systems. Numbers of individuals in both systems and both crops (winter wheat and winter rape) are summarized in Figures 1 and 2. Total 
abundance as well as total activity-density is significantly higher on sites with conventional management in both wheat ( $p \leq 0.001$ and $p \leq 0.05$, respectively) and rape $(p \leq 0.001)$ crops. Beetles and spiders are among the most active-dense animals in both crops, therefore these model groups at species level were studied. Although beetles are more active-dense in conventionally managed crops (similar to ants in wheat crops), the spiders prefer sites with organic management in both crops, similar to harvestmen in rape crops (Fig. 1). On the other hand, conventional sites of both wheat and rape are preferred by soil-dwelling animals, where abundance in soil samples is significantly higher for larvae of beetles as well as for springtails (in wheat only) or mites and millipedes (in rape only) (Fig. 2).



Note. The number of trapped beetles (Coleoptera) was reduced ten times for lucidity and is highlighted by hatching; significant differences between plots with different management are highlighted by asterisks: ${ }^{*}-p \leq 0.05,{ }^{* *}-p \leq 0.01$ and ${ }^{* * *}-p \leq 0.001$.

Figure 1. Comparison of mean year activity-density of soil surface active animals on wheat and oilseed rape sites managed organically and conventionally

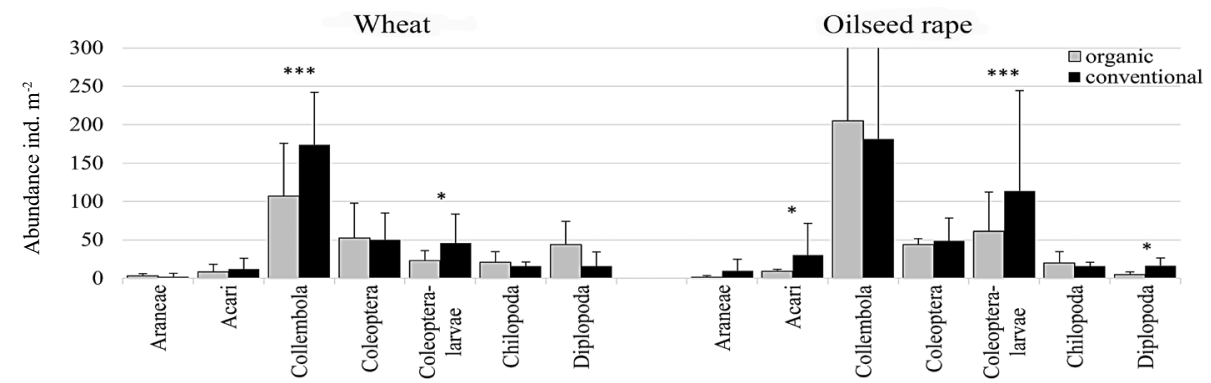

Note. Significant differences between abundance on plots with different management are highlighted by asterisks: $*-p \leq 0.05$, $* *-p \leq 0.01$ and $* * *-p \leq 0.001$.

Figure 2. Comparison of mean year abundance of heat extracted soil-dwelling animals on wheat and oilseed rape sites managed organically and conventionally

\section{Carabid beetles in different crops and farming} systems. When interpreting the results (via PCA analysis) of beetle species trapped in different crops and farming systems, it is apparent that the crop species is more significant (in terms of species difference) than the farming system used (Fig. 3). Irrespective of crop preference, the most dominant species Pterostichus melanarius is more active on conventionally managed plots (both crops: $p \leq 0.001$ ). The same significant pattern is visible on rape sites for Anchomenus dorsalis and Poecilus cupreus (both: $p \leq 0.001$ ), whereas Brachinus crepitans predominates on organically managed rape plots $(p \leq 0.001)$. On the other hand, on wheat plots P. cupreus along with Pseudoophonus rufipes and Amara ovata prefer plots under organic management $(p \leq 0.001$, $p \leq 0.01$ and $p \leq 0.05$, respectively). Other species show no significant difference in activity pattern between plots under different management.

Spiders in different crops and farming systems. In contrast to carabids, PCA analysis of spider species found in different crops and farming systems shows not only the influence of crop species but also the impact of the farming system used (Fig. 4).

Irrespective of crop preference, the most activedense species Oedothorax apicatus was, in terms of rape crops, more numerous on sites under organic management $(p \leq 0.001)$. The same significant pattern was visible on sites of both crops for Pachygnatha degeeri and Pardosa agrestis $(p \leq 0.001, P$. degeeri on rape plots $-p \leq 0.05)$. This preference was significant also for Drassyllus pusillus on wheat sites and Erigone atra on

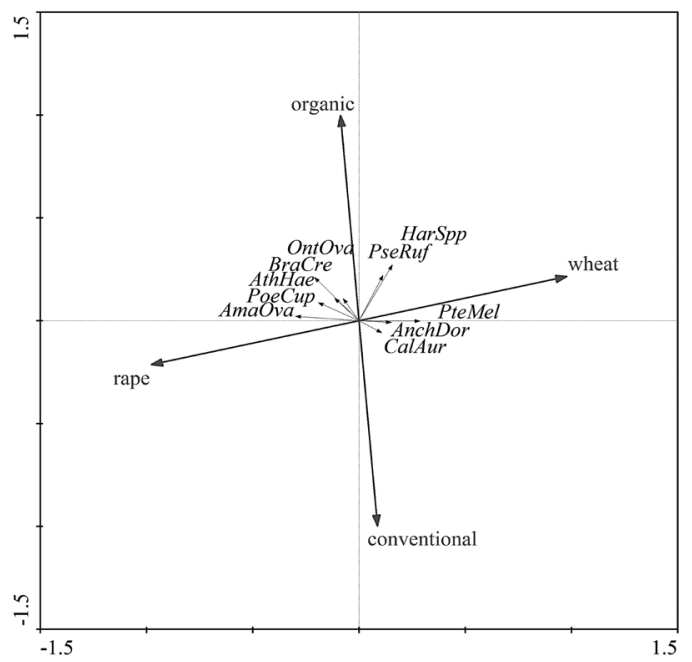

Note. AmaOva - Amara ovata, AnchDor - Anchomenus dorsalis, AthHae - Athous haemorrhoidalis, BraCre Brachinus crepitans, CalAur - Calosoma auropunctatum, HarSpp - Harpalus spp., OntOva - Onthophagus ovatus, PoeCup - Poecilus cupreus, PseRuf-Pseudoophonus rufipes, PteMel - Pterostichus melanarius; environmental variables with significant contribution to model are highlighted in larger typeface; the first axis describes $55.9 \%$, while the whole model describes $65.7 \%$ of variability in species distribution.

Figure 3. Principal component analysis (PCA) of beetle species found in different crops and farming systems 


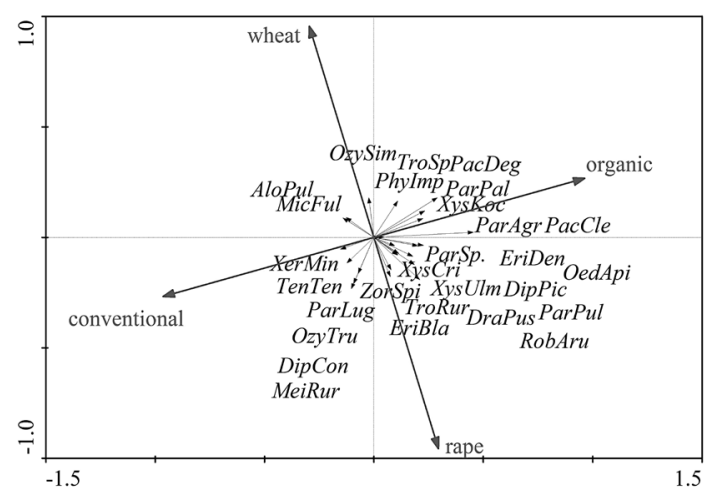

Note. AloPul-Alopecosa pulverulenta,DipPic-Diplocephalus picinus, DipCon - Diplostyla concolor, DraPus - Drassyllus pusillus, EriBla - Erigone atra, EriDen - Erigone dentipalpis, MeiRur - Meioneta rurestris, MicFul - Micaria fulgens, OedApi - Oedothorax apicatus, OzySim - Ozyptila simplex, OzyTru - Ozyptila trux, PacCle - Pachygnatha clercki, PacDeg - Pachygnatha degeneri, ParAgr - Pardosa agrestis, ParLug - Pardosa lugubris, ParPal - Pardosa palustris, ParPul - Pardosa pullata, ParSp. - Pardosa sp., PhyImp Phylloneta impressa, RobAru - Robertus arundineti, TenTen - Tenuiphantes tenuis, TroRur - Trochosa ruricola, TroSp. Trochosa sp., XerMin - Xerolycosa miniata, XysCri - Xysticus cristatus, XysKoc - Xysticus kochi, XysUlm - Xysticus ulmi, ZorSpi - Zora spinimana; all environmental variables have significant contribution to model; the first axis describes $42.3 \%$, while the whole model describes $57.7 \%$ of variability in species distribution.

Figure 4. Principal component analysis (PCA) of spider species found in different crops and farming systems

rape sites (both $p \leq 0.001$ ), whereas $E$. atra predominated on conventionally managed wheat plots $(p \leq 0.001)$. Another species with a slight significant preference for conventionally managed plots was Pardosa pullata on plots of rape $(p \leq 0.05)$. Other species showed no significant difference in activity pattern between plots under different management.

\section{Discussion}

Over a four-year period, the effect of organic and conventional agriculture on soil invertebrates was studied in winter wheat and winter oilseed rape fields. Plots under organic agriculture did not support greater abundance of soil invertebrates at all. Conventionally managed plots were more favourable for ground beetles (cf. Rana et al., 2010), whereas organically managed plots supported abundance of spiders.

It can be quite difficult to actually determine the influence of different farming systems, as the abundance of arthropods varied considerably within each farming system, sometimes more than between organic and conventional farming. Many factors such as soil characteristics, plant diversity within fields, soil tillage and non-crop habitat in the surrounding environment affect ground beetles, and this could explain the variable results (Holland, Luff, 2000). Change may even occur in the course of time, due to changes in farming systems (Rusch et al., 2013). Puech et al. (2014) suggest that farmers can implement strategies that enhance populations of natural enemies within crops, regardless of whether the farms have received organic certification. These authors also show that there is enough flexibility in the strategies of both farming systems to enhance natural enemy populations. They found that the different responses, which we also found for ladybirds, carabid beetles and parasitoids, emphasized the need to account for a large spectrum of groups of species when studying the effects of farming practices on communities of natural enemies of crop pests and biological control. In research by Diekötter et al. (2010) ground beetle activity as well as diversity was neither affected by management type nor landscape composition spider activity but not diversity, tended to be affected by landscape composition showing higher activity in conventional management than organic management. Predaceous carabid species may benefit from increased availability of potential herbivore prey in highly productive conventionally managed wheat fields and may later shift to organic fields, as they offer ample seeds and prey due to their diversity of arable weeds (Rivers et al., 2018).

It is not easy to judge the effect of organic and conventional agriculture on biodiversity, even due to the fact that conventional systems often involve elements of organic farming and vice versa (Thorbek, Bilde, 2004). There are often considerable differences between organic and conventional agriculture in particular conditions, which does not only mean the use of pesticides but also the way the soil is tilled. In some cases these interventions can be quite a harmful factor in terms of biodiversity of soil fauna (Silva et al., 2018). These authors state that physical disturbance (e.g., ploughing) is a key factor affecting biotic activity and species diversity in agroecosystems. A ground beetle, predator of crop pests Pterostichus melanarius, can be significantly more numerous in minimum tillage than frequent tillage conditions. Small carabids (as Anchomenus dorsalis) can, according to references, be even more abundant in frequent tillage conditions (Kennedy et al., 2013), as these fields are characterised by less competition from larger species. The systems examined in our study also differed in mechanical intervention, where organically farmed land was tilled intensively (Table), i.e. using hoeing and harrowing to eliminate weeds. For each crop, spraying with pesticides, often in early spring when most species are wintering in the soil, seemed to have relatively less impact (e.g., on dominant $P$. melanarius populations) than tillage. Similarly Legrand et al. (2011) reported that under both organic and conventional management, intensive deep tillage during the reproduction period resulted in rapid population extinction of $P$. melanarius despite the presence of grass margins. Our results agree with this conclusion that the spread of $P$. melanarius larvae due to farming practices was the key to species presence in crop fields. Compared with harrowing, hoeing is a more intensive and deeper intervention to the soil environment. This finding can be taken as a general recommendation for the timing of mechanical interventions, either as early as possible (while respecting other circumstances) or later, when carabids are in the imago stage (if this does not destroy the crop). Organic management could be less effective as it requires repeated soil tillage to compensate for the lack of herbicide use.

In research by Doring and Kromp (2003) Amara species were more active in organic crops; we confirmed this result in wheat plots only. As $A$. ovata feeds on plant seeds, the high activity of this species in oilseed rape could indicate a preference for crops other than cereals (Eyre et al., 2013) due to highly selective herbicides in wheat fields. The activity of Brachinus crepitans followed the activity of Amara, as its larvae parasitize on Amara pupae.

In the case of spiders, a reduction in mechanical disturbance of soil increased diversity (Thorbek, Bilde, 2004), whereas direct destruction of spiders (mainly larger species) or their prey, or negative effects on habitat heterogeneity, were the most likely reasons for reduced abundance. In our study abundance of Pardosa agrestis was higher on organically farmed fields, despite mechanical disturbance. Mechanical management was carried out in autumn and spring, during this period this 
species was juvenile (smaller body size) and mechanical disturbance had a lesser impact on it.

More spider specimens were found on organically farmed plots, which were confirmed by several studies, e.g., Batáry et al. (2012) and Feber et al. (2015). Organically farmed crops are usually less dense and occasionally disturbed by mechanical intervention against weeds. Locations which are light and disturbed suit light-dependent spider species, proven by the higher abundance of the dominant species, Oedothorax apicatus and $P$. agrestis, in organic oilseed rape. These spiders are effective in controlling pests. The lower spider density in oilseed rape is testified by a much lower yield than in the conventional treatment (Table).

High species richness of weeds in fields can increase spider diversity, because more host plants increase the amount of prey for spiders (Batáry et al., 2012). The conventional system using pesticides have an indirect impact on spiders - decrease abundance and quality of prey. In wheat, the $P$. agrestis species was more abundant in the organic system, which enables easier movement for actively hunting wolf spiders (both Pardosa and Trochosa species). On the other hand, increased abundance of small spider species (particularly Linyphiidae) in a conventional agriculture system should be due to better and faster colonisation by ballooning (Feber et al., 2015). These small spiders were less affected by the use of pesticides than by mechanical disturbance of soil in organic farming. Higher abundance of millipedes in conventional oilseed rape can correspond with higher humidity and amount of organic litter. Millipedes are hygrophilous and detritovorous, the presence of dead organic matter is an important factor affecting the number of millipedes (Berg, Hemerik, 2004).

\section{Conclusions}

1. Carabid populations were negatively affected by mechanical disturbances of soil on the plots of organic wheat, as documented from the $1^{\text {st }}$ year of evaluation, when, due to a warm winter, farmers carried out these interventions sooner with no effect on carabids. By contrast, in the $4^{\text {th }}$ year of evaluation, following deep snow cover, the soil surface was harrowed four times (compared with only three times in previous years) with negative effect on carabid communities. Mechanical interventions may not be a problem for spiders as they over-winter in field margins and surrounding grassy sites.

2. It seems evident that individual taxa of the same ecological group - soil-dwelling fauna in this case - respond differently to the effects of long-term organic farming. Rejecting some conventional technologies and replacing these with an organic system can result in an uncontaminated harvest, but on the other hand, it can negatively affect some animal species. When considering individual interventions within the system, its biological and ecological context must be taken into account. In terms of agroecosystems, this means applied ecology or ecology of food systems. Properly targeted management, with regard to the requirements of individual species, can be more important than the choice of a farming system. A credible evaluation of all positive and negative effects should be carried out before choosing the best farming system.

\section{Acknowledgements}

The authors would like to express their thanks to the Czech National Agency for Agricultural Research (projects QK1720303 and QK1810233) for its help in completing this article. The authors are thankful to two anonymous reviewers for their suggestions.

Received 16062018

Accepted 22022019

\section{References}

1. Arus L., Kikas A., Luik A. 2012. Carabidae as natural enemies of the raspberry beetle (Byturus tomentosus $\mathrm{F}$.). Zemdirbyste-Agriculture, 99 (3): 327-332.

2. Batáry P., Holzchuh A. Orci K. M., Samu F., Tscharntke T. 2012. Responses of plant, insect and spider biodiversity to local and landscape scale management intensity in cereal crops and grasslands. Agriculture, Ecosystems and Environment, 146: 130-136.

https://doi.org/10.1016/j.agee.2011.10.018

3. Bengtsson J., Ahnström J., Weibull A. C. 2005. The effect of organic agriculture on biodiversity and abundance: a meta-analysis. Journal of Applied Ecology, 42: 262-269. https://doi.org/10.1111/j.1365-2664.2005.01005.x

4. Berg M. P., Hemerik L. 2004. Secondary succession of terrestrial isopod, centipede, and millipede communities in grasslands under restoration. Biology and Fertility of Soils, 40: 163-170. https://doi.org/10.1007/s00374-004-0765-z

5. Birkhofer K., Ekroos J., Corlett E. B., Smith H. B. 2014 Winners and losers of organic cereal farming in animal communities across Central and Northern Europe. Biological Conservation, 175: 25-33.

https://doi.org/10.1016/j.biocon.2014.04.014

6. Bruno J. F., Cardinale B. J. 2008. Cascading effects of predator richness. Frontiers in Ecology and the Environment, 6: 539-546. https://doi.org/10.1890/070136

7. Cardoso E. J. B. N., Vasconcellos R. L. F., Bini D., Miyauchi M. Y. H., dos Santos C. A., Alves P. R. L., de Paula A. M., Nakatani A. S., Pereira J. D., Nogueira M. A. 2013. Soil health: looking for suitable indicators. What should be considered to assess the effects of use and management on soil health? Scientia Agricola, 70 (4): 274-289. https://doi.org/10.1590/S0103-90162013000400009

8. Diekötter T., Wamser S., Wolters V., Birkhofer K. 2010 Landscape and management effects on structure and function of soil arthropod communities in winter wheat. Agriculture, Ecosystems and Environment, 137: 108-112. https://doi.org/10.1016/j.agee.2010.01.008

9. Doring T. F., Kromp B. 2003. Which carabid species benefit from organic agriculture? A review of comparative studies in winter cereals from Germany and Switzerland. Agriculture, Ecosystems and Environment, 98: 153-161. https://doi.org/10.1016/S0167-8809(03)00077-X

10. Dytrtová K., Sarapatka B., Opršal Z. 2016. Does organic farming influence landscape composition? Two cases from the Czech Republic, Agroecology and Sustainable Food Systems, 40: 714-735. https://doi.org/10.1080/21683565.2016.1186131

11. EC. 2007. Council Regulation (EC) No $834 / 2007$ of 28 June 2007 on organic production and labelling of organic products and repealing Regulation (EEC) No. 2092/91. https://eur-lex.europa.eu/eli/reg/2007/834/oj

12. Ekroos J., Hyvonen T., Tiainen J., Tiira M. 2010 Responses in plant and carabid communities to farming practises in boreal landscapes. Agriculture, Ecosystems and Environment, 135: 288-293. https://doi.org/10.1016/j.agee.2009.10.007

13. Eyre M.D., Luff M. L., Leifert C. 2013. Crop, field boundary, productivity and disturbance influences on ground beetles (Coleoptera, Carabidae) in the agroecosystem. Agriculture, Ecosystems and Environment, 165: 60-67. https://doi.org/10.1016/j.agee.2012.12.009

14. Feber R. E., Johnson P. J., Bell J. R., Chamberlain D. E., Firbank L. G., Fuller R. J., Manley W., Mathews F., Norton L., Townsend M., MacDonald D. W. 2015. Organic farming: biodiversity impact can depend on dispersal characteristics and landscape content. PLoS ONE $10(8)$ : e0135921. https://doi.org/10.1371/journal.pone.0135921

15. Fuller R. J., Norton L. R., Feber R. E., Johnson P. J., Chamberlain D. E., Joys A. C., Mathews F., Stuart R. C., Townsend M. C., Manley W. J., Wolfe M. S., MacDonald D. W., Firbank L. G. 2005. Benefits of organic farming to biodiversity vary among taxa. Biology Letters, 1: 431-434. https://doi.org/10.1098/rsbl.2005.0357

16. Holland J. M., Luff M. L. 2000. The effects of agricultural practices on Carabidae in temperate agroecosystems. Integrated Pest Management Reviews, 5 (2): 109-129. https://doi.org/10.1023/A:1009619309424

17. Holland J. M., Thomas C. F. G., Birkett T., Southway S., Oaten H. 2005. Farm-scale spatiotemporal dynamics of predatory beetles in arable crops. Journal of Applied Ecology, 42: 1140-1152.

https://doi.org/10.1111/j.1365-2664.2005.01083.x 
18. Kennedy T. F., Connery J., Fortune T., Forristal D., Grant J. 2013. A comparison of the effects of minimumtill and conventional-till methods, with and without straw incorporation, on slugs, slug damage, earthworms and carabid beetles in autumn-sown cereals. Journal of Agricultural Science, 151: 605-629. https://doi.org/10.1017/S0021859612000706

19. Kromp B. 1999. Carabid beetles in sustainable agriculture: a review of pest control efficacy, cultivation impacts and enhancement. Agriculture, Ecosystems and Environment, 74: $187-228$. https://doi.org/10.1016/S0167-8809(99)00037-7

20. Legrand A., Gaucherel C., Baundry J., Meynard J. M. 2011. Long-term effects of organic, conventional, and integrated crop systems on Carabids. Agronomy for Sustainable Development, 31 (3): 515-524.

https://doi.org/10.1007/s13593-011-0007-3

21. Levin G. 2007. Relationships between Danish organic farming and landscape composition. Agriculture, Ecosystems and Environment, 120: 330-344. https://doi.org/10.1016/j.agee.2006.10.018

22. Puech C., Baundry J., Joannon A., Poggi S., Aviron S. 2014. Organic $v s$. conventional farming dichotomy: does it make sense for natural enemies? Agriculture, Ecosystems and Environment, 194: 48-57.

https://doi.org/10.1016/j.agee.2014.05.002

23. Rahmann G. 2011. Biodiversity and organic farming: what do we know? Landbauforschung, 61 (3): 189-208.

24. Rana N., Rana S. A., Khan H. A., Sohail A. 2010. Assessment of possible threats to soil macro-invertebrates diversity in wheat fields from high input farming. International Journal of Agriculture and Biology, 12: 801-808.

25. Riechert S. E. 1998. The role of spiders and their conservation in the agroecosystem. Pickett C. H., Bugg R. L. (eds). Enhancing biological control: habitat management to promote natural enemies of agricultural pests. University of California Press, p. 211-237.

26. Rivers A. N., Mullen C. A., Barbercheck M. E. 2018. Cover crop species and management influence predatory arthropods and predation in an organically managed, reduced-tillage cropping system. Environmental Entomology, 47: 340-355. https://doi.org/10.1093/ee/nvx149

27. Roschewitz T. Gabriel D., Tscharntke T., Thies C. 2005. The effect of landscape complexity on arable weed diversity in organic and non-organic farming. Journal of Applied Ecology, 42 (5): 873-882. https://doi.org/10.1111/j.1365-2664.2005.01072.x

28. Rusch A., Bommarco R., Chiverton P., Oberg S., Wallin H., Wiktelius S., Ekbom B. 2013. Response of ground beetle (Coleoptera, Carabidae) communities to changes in agricultural policies in Sweden over two decades. Agriculture, Ecosystems and Environment, 176: 63-69. https://doi.org/10.1016/j.agee.2013.05.014

29. Schneider M. K., Luscher G., Jeanneret P. et al. 2014. Gains to species diversity in organically farmed fields are not propagated to the farm level. Nature Communications, 5: 4151. https://doi.org/10.1038/ncomms5151

30. Silva R. A., Siqueira G. M., Costa M. K. L., Guedes Filho O., Silva E. F. F. 2018. Spatial variability ofsoil fauna under different land use and managements. Revista Brasileira de Ciência do Solo, 42: e0170121. https://doi.org/10.1590/18069657rbcs20170121

31. Soderman A. M. E., Ekroos J., Hedlund K., Olsson O., Smith H. G. 2016. Contrasting effects of field boundary management on three pollinator groups. Insect Conservation and Diversity, 9: 427-437.

https://doi.org/10.1111/icad.12179

32. Stockdale E. A., Watson C. A. 2009. Biological indicators of soil quality in organic farming systems. Renewable Agriculture and Food Systems, 24 (4): 308-318. https://doi.org/10.1017/S1742170509990172

33. Sunderland K. D., Samu F. 2000. Effects of agricultural diversification on the abundance, distribution, and pest control potential of spiders: a review. Entomologia Experimentalis et Applicata, 95: 1-13. https://doi.org/10.1046/j.1570-7458.2000.00635.x

34. ter Braak C. J. F., Šmilauer P. 1998. CANOCO reference manual and user's guide to Canoco for Windows: software for canonical community ordination (version 4). Centre for Biometry, $351 \mathrm{p}$.

35. Thorbek P., Bilde T. 2004. Reduced numbers of generalist arthropod predators after crop management. Journal of Applied Ecology, 41: 526-538. https://doi.org/10.1111/j.0021-8901.2004.00913.x

36. Tscharntke T., Tylianakis J. M., Rand T. A. et al. 2012. Landscape moderation of biodiversity patterns and processes - eight hypotheses. Biological Reviews, 87 (3): 661-685. https://doi.org/10.1111/j.1469-185X.2011.00216.x

37. Tuf I. H., Tvardík D. 2005. Heat-extractor - an indispensable tool for soil zoological studies. Tajovský $\mathrm{K}$. et al. (eds). Contributions to soil zoology in Central Europe I. České Budějovice, Czech Republic, p. 191-194.

38. Vasseur C., Joannon A., Aviron S., Burel F., Meynard J. M., Baudry J. 2013. The cropping systems mosaic: how does the hidden heterogeneity of agricultural landscapes drive arthropod populations? Agriculture, Ecosystems and Environment, 166: 3-14. https://doi.org/10.1016/j.agee.2012.08.013

39. WRB. 2014. World reference base for soil resources. World soil resources reports No. 106. FAO, p. 189.

ISSN 1392-3196 / e-ISSN 2335-8947

Zemdirbyste-Agriculture, vol. 106, No. 4 (2019), p. 291-296

DOI 10.13080/z-a.2019.106.037

\title{
Ūkininkavimo sistemų ir žemès dirbimo būdų įtaka dirvožemio paviršiaus makrofaunai
}

\author{
V. Chmelík, B. Šarapatka, O. Machač, J. Mikula, V. Laška, I. H. Tuf \\ Palacký universiteto Tiksliujų mokslų fakultetas, Čekijos Respublika
}

\section{Santrauka}

Nors dèl šiuolaikiniožemès ūkio veiklos bestuburių gyvūnųịvairovėmažèja, tikimasi, kad šiąneigiamąitaką sumažins ekologinis ūkininkavimas. Tyrimo metu palygintos dirvos paviršiuje gyvenančios makrofaunos bendruomenės laukuose, kuriuose pastaruosius 15 metu buvo taikyta tradicinè ir ekologinè žemdirbystė sèjomainoje su žieminiais rapsais ir žieminiais kviečiais. Iš esmès didesnis kiekis makrofaunos individų buvo nustatytas abiejų kultūrų laukuose taikant tradicinę žemdirbystę. Gausiausias grupes sudarè žemės (Carabidae (žygių) šeimos) vabalai ir vorai. Vorų daugiau nustatyta ekologiniuose laukuose, žygių - augalus auginant tradiciškai, kur jie buvo veikiami pavasarinio mechaninio žemès dirbimo (akèjimo ir purenimo). Šios priemonès nebuvo reikšmingos vorams, nes jie peržiemoja laukų pakraščiuose, labai gerai plinta oru ir geba greitai iš naujo kolonizuoti agroekosistemas. Tai rodo, kad ekologinis ūkininkavimas nebūtinai palaiko dirvožemio faunos populiacijų ir bendruomenių vystymąsi.

Reikšminiai žodžiai: agrotechnika, Araneae, Carabidae, dirvožemio fauna, ekologinis ūkininkavimas, tradicinis ūkininkavimas. 